\title{
Difficulties Faced in Body Donation during Unprecedented Covid-19 Times
}

\author{
Preksha Sharma ${ }^{1}$, Neha Sharma ${ }^{2,{ }^{*},}$ Nandlal ${ }^{1}$ \\ ${ }^{1}$ Department of Anatomy, SMS Medical College and Attached Hospitals, Jaipur, Rajasthan, INDIA. \\ ${ }^{2}$ Department of Pharmacology, SMS Medical College and Attached Hospitals, Jaipur, Rajasthan, INDIA.
}

To the Editor,

Anatomy is the study of structural configuration of human body. ${ }^{1}$ Body donation is the act of giving one's body for research and education, after death. Human cadavers are the silent teachers and the foremost ones for a medical student. They are unparalleled to any other form of teaching and play a cardinal role in medical pedagogy. ${ }^{2}$ The study of anatomy is incomplete without dissection. ${ }^{3}$ The word anatomy itself means to cut open. It helps the students in learning about the topography of the organs and other structures present in a human body. ${ }^{4}$

Anatomy lays the foundation for all the surgical subjects like Ophthalmology, Otorhinology, Orthopaedics, General surgery etc. The source of cadavers in our medical college is either unclaimed bodies or voluntary body donation whereas in some of the medical colleges donation remains the only source of cadaver. ${ }^{5}$ Teaching anatomy, as well as learning, becomes quite difficult without the dissection of a cadaver. ${ }^{6,7} \mathrm{With}$ each passing year, number of students getting admitted into medical, dental as well as paramedical faculties is increasing significantly, which leads to increasing demand for cadavers for teaching anatomy. ${ }^{8}$ Cadaver dissection is one of the finest source of knowledge for medical students to learn the subject. ${ }^{9}$

Integration of technology in education is an ever evolving concept. In the current, unprecedented times of Coronavirus Disease (COVID-19), when the whole country was under lockdown, and the directives being issued by the Ministry of Health and Family Welfare, Government of India, and Board of Governors of

\begin{tabular}{|l|c|}
\hline \multicolumn{2}{|c|}{ Access this article online } \\
\hline $\begin{array}{l}\text { Website: } \\
\text { www.jcramonline.com }\end{array}$ & Quick Response code \\
\hline DOI: & \\
10.5530/jcram.1.1.8 & \\
& \\
\hline
\end{tabular}

Article Information

Received: 11-05-2021

Revised : 12-06-2021

Accepted: 29-07-2021

Correspondence
Dr. Neha Sharma
Assistant Professor, Department of
Pharmacology, SMS Medical College and
Attached Hospitals, Jaipur, Rajasthan, INDIA.
Phone: +919024374979.
E-mail: nsharma226@gmail.com

Medical Council of India, the increasing need for the use of technology has surfaced. However, teaching dissection through online classes still remains a challenging job. ${ }^{10}$ The Guidelines regarding dead body management in the times of COVID-19 have been issued by Government of India, Ministry of Health and Family Welfare, Directorate General of Health Services, Emergency Medical Relief Division (EMR Division).

There is a lacunae in the knowledge regarding the proper disposition of dead body of a covid suspect as well as a confirmed case. Therefore, World Health Organization (WHO) issued necessary guidelines regarding the same. As per the guidelines, there is not much risk involved in the handling of dead body during COVID-19 pandemic, if proper safety precautions are observed. The main source of transmission of COVID-19 is through droplets. The lungs of a dead corona infected patient can be infectious, therefore should be handled with extra precaution during autopsy. It is recommended that the health care workers should follow standard precautions like hand hygiene, use of personal protective equipments (PPE), safe handling of sharps, disinfecting the bag containing dead body, instruments and linen. All the staff involved in handling of dead bodies should be trained in infection prevention control practices. All the drains, catheter and tubes if present in 
the body should be carefully removed. All the wounds if any, puncture holes should be immediately disinfected with $1 \%$ hypochlorite and should be sealed with impenetrable material and all the orifices of the body should be stoppled in an order to prevent leakage of body fluids. All the sharp devices should be disposed into different sharp containers. Body should be placed in a leak proof bag made of plastic and the outer surface of bag should be sanitized with hypochlorite.

According to the guidelines laid by the Ministry of health and family welfare, the body can either be handed over to the relatives or can be sent to the mortuary. Medical waste, soiled linen, equipments should be taken care of, disinfected and disposed in accordance with the bio medical waste management and infection prevention control practices. Surfaces of the isolation including the high touch and low touch points should be cleaned with $1 \%$ hypochlorite. According to the guidelines, embalming of the dead body should not be permitted and autopsies should be avoided as far as possible. If at all an autopsy is to be performed, then it should be done by obeying infection prevention control practices. In an order to avoid the spread of COVID-19 virus, large gatherings at the burial ground/ crematorium should be avoided as the family members of the deceased may be symptomatic or shedding the virus. ${ }^{11,12}$

With the current situation of pandemic going on in the world, the anatomists have a huge consternation, whether body donation should be undertaken or not. With the increasing number of students enrolling in various faculties, there is a dire need to escalate the body donation program, but in current times, safety of our healthcare professionals should also be kept in mind.

\section{REFERENCES}

1. Standring S, Borley NR, Gray H. Gray's anatomy: the anatomical basis of clinical practice. 40th ed; 2008, anniversary ed. [Edinburgh]: Churchill Livingstone/ Elsevier.

2. Ajita R, Singh I. Body donation and its relevance in anatomy learning: a review. J Anat Soc India. 2007;56:44-7.

3. Dhamangaonkar AC. Cadaver the great teacher. Available from: https://www. kem.edu/wp-content/uploads/2012/06/Cadaver_The_Great_Teacher.pdf [cited 2/8/2021].

4. Rokade SA, Bahetee BH. Body donation in India: a review. Int J Res Med Sci. 2013;1(3):17-177. doi: 10.5455/2320-6012.jjrms20130814.

5. Agthong S, Wiwanitkit V. Cadaver donation: a retrospective review at the King Chulalongkorn Memorial Hospital, Bangkok. Southeast Asian J Trop Med Public Health. 2002;33(3):166-7.

6. Saha A, Sarkar A, Mandal S. Body donation after death: the mental setup of educated people. J Clin Diagn Res. 2015;9(6):AC05-AC9. doi: 10.7860/ JCDR/2015/12246.6011, PMID 26266106.

7. Reddy AV, Guleria S, Khazanchi RK, Bhardwaj M, Aggarwal S, Mandal S. Attitude of patients, the public, doctors, and nurses toward organ donation. Transplant Proc. 2003 Feb;35(1):18. doi: 10.1016/s0041-1345(02)03792-2, PMID 12591287.

8. Sakai T. Body donation: an act of love supporting anatomy education. The $\mathrm{J}$ Jpn Asso. 2008;51(1):39-45.

9. Karau PB, Wamachi A, Ndede K, Mwamisi J, Ndege P. Perception to cadaver dissection and views on Anatomy as a subject between two pioneer cohorts in a Kenyan Medical School. Anat J Afr. 2014;3(2):318-23.

10. Ravi KS. Dead body management in times of Covid-19 and its potential impact on the availability of cadavers for medical education in India. Anat Sci Educ. 2020;13(3):316-7. doi: 10.1002/ase.1962, PMID 32279462.

11. COVID-19: guidelines on dead body management. Government of India, Ministry of Health and Family Welfare, directorate General of Health Services (EMR division). Availablefrom. Available from: https://www.mohfw.gov. in/1584423700568_COVID19GuidelinesonDeadbodymanagement.pdf [cited 2/8/2021].

12. Lai CC, Shih TP, Ko WC, Tang HJ, Hsueh PR. Severe acute respiratory syndrome coronavirus 2 (SARS-CoV-2) and coronavirus disease-2019 (COVID-19): the epidemic and the challenges. Int J Antimicrob Agents. 2020;55(3):105924. doi: 10.1016/j.jjantimicag.2020.105924.

Cite this Article : Sharma P, Sharma N, Nandlal. Difficulties Faced in Body Donation during Unprecedented Covid-19 Times. J. Clin. Res. Applied Med. 2021;1(1):32-3. 